vividly describes her first drawing-room appearance at "The Palace":

"Nov. I2, $18 \mathrm{r} 2$ - On Tuesday, William and I repaired to the palace between four and five o'clock, our carriage setting us down after the first comers, and before the last. It is customary, on whatever occasion, to advance to the upper end of the room, pay your obeisance to Mrs. Madison, courtesy to his HIGHNESS, and take a seat; after this ceremony being at liberty to speak to acquaintances, or amuse yourself as at another party."

Again, after a New Year's call in I8I4, she wrote in her diary: "Her majesty's appearance was truly regal, - dressed in a robe of pink satin, trimmed elaborately with ermine, a white velvet and satin turban, with nodding ostrich plumes and a crescent in front, gold chain and clasps around the waist and wrists." It would seem, however, that Madison's regime was the last one wherein such conventions prevailed, as, with the growth of a national consciousness, we were no longer dependent on Europe for our ideas of dignity and importance.

\title{
The First Thames Tunnel
}

TUNNEL - what imaginative pictures are conjured up in our minds on hearing this word! To most of us come visions of trains swooping through impassable mountains. Few of us would think of a tunnel as a foot-path or carriage-way under a river, but the first successful tunnel was just such a project under the Thames River.

An unusual little book entitled Introduction to a View of the Works for the Tunnel under the T'hames from Rotherhithe to Wapping, published by D. K. Minor and George C. Schaeffer, New York, in 1836, has recently come into the possession of the Society through the courtesy of Mr. Charles H. Taylor. This little volume was based on a similar book entitled Sketches of the Works for the Tunnel under the Thames from Rotherhithe to Wapping, published by Messrs. Harvey and Darton, Fleet Street, in I829, and in fact the illustrations for our volume were taken directly from the earlier work.

According to this account, the "immense" mercantile concerns which were situated on the Thames River in the neighborhood of London Bridge made it of the utmost importance to provide an easy means of transportation from shore to shore by land. As early as 1799 a project to put a tunnel under the river at Gravesend was advanced, but the idea was soon abandoned. Five years later, 
under the authority of an Act of Parliament, an attempt was made to put a tunnel from Rotherhithe to Limehouse. At this time a shaft was sunk to a depth of seventy-six feet and at this level a small tunnel or driftway was extended to but one hundred and fifty feet of the opposite shore. However, so many difficulties were here encountered that the project was again abandoned. Various other plans were suggested for tunnelling under the Thames, but all were "tabled" as impractical.

In I 8 I 8 Marc I. Brunel, C.E., F.R.S., perfected and patented his tunnelling process which included the use of a cast-iron shield. This shield, which was the predecessor of our modern shield, apparently made use of iron for construction for the outer walls, but used timber for the twelve great frames contained therein, "lying close to each other, like as many volumes on the shelf of a bookcase; these frames are 22 feet in height, and about 3 feet in breadth. They are divided into 3 stages or stories, thus representing 36 chambers, or cells for the operators to work in - namely, the miners, by whom the ground is cut down and secured in front, and the bricklayers, by whom the structure is simultaneously formed from the back of these cells."

Five years later Mr. Brunel proposed his scheme for constructing a double arcade, with frequent archways in between, forming a roadway under the Thames with the use of the shield. His proposal was enthusiastically received and liberally supported by important persons of the day. It was decided to make this attempt at Rotherhithe, which is about two miles below London Bridge, as it was perhaps the only spot situated between London Bridge and Greenwich at which such a project could be carried on without interfering with some of the "immense" mercantile establishments. The neighborhood was highly commercial and very populous, and a facility of communication between the two shores was therefore highly desirable at this location, being of benefit not only to the immediate communities but to the adjacent counties as well. Borings were taken of the river and the project was declared feasible by engineers, and as a consequence the company was incorporated on June 24, I824, with Mr. Brunel as chief engineer. The river at this point was $I, 000$ feet wide and the whole length of the tunnel from shaft to shaft was to be $I, 300$ feet.

This tremendous undertaking was commenced by sinking a brick shaft about one hundred and fifty feet from the river, by the method then in practice for sinking well shafts. The horizontal excavation for the body of the tunnel was begun at sixty-three feet and was 


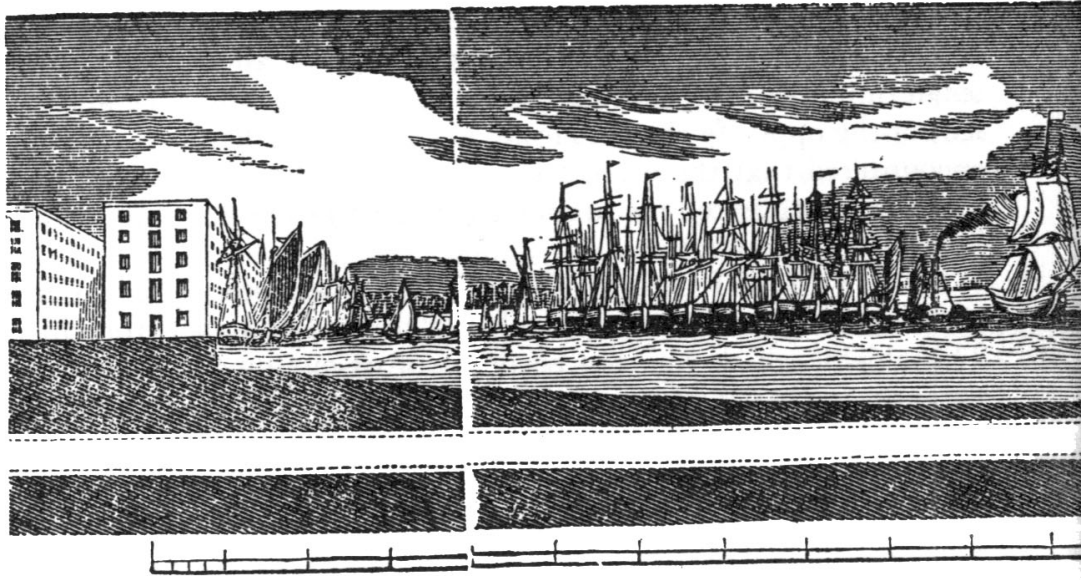

The Thames

about thirty-eight feet wide and twenty-two feet in height. Our little volume comments on the size of the opening by making a comparison: "For a more comprehensive illustration of the magnitude of the excavation made for the tunnel under the Thames, it may not be improper to mention, that it is larger than the interior of the old House of Commons, which, being 32 feet in breadth by 25 feet in height, was only $8 \mathrm{co}$ feet in sectional area; and it may further be observed, that the base of this excavation, in the deepest part of the river, is 75 feet below high water." This depth was reached by carrying on the excavation at a declivity of two feet three inches per hundred feet, as the deepest part of the river necessitated such depth.

The work of excavation was constantly threatened by disaster, for though the shield which had been placed in position on January $I, 1826$, under which the work was carried on, was described as being "powerful and efficient," nevertheless the tidal action on the strata of the river bed tended to multiply the difficulties, and also occasionally to give them an "awful" character. Less than a month after commencing the entrance, the clay protection broke off leaving the shield exposed for more than six weeks to an influx of land and water. This was cleared in March and the shield being again under a clay bed, work proceeded and arrived by June within the margin of the river. By April, 1827 , it had advanced four 


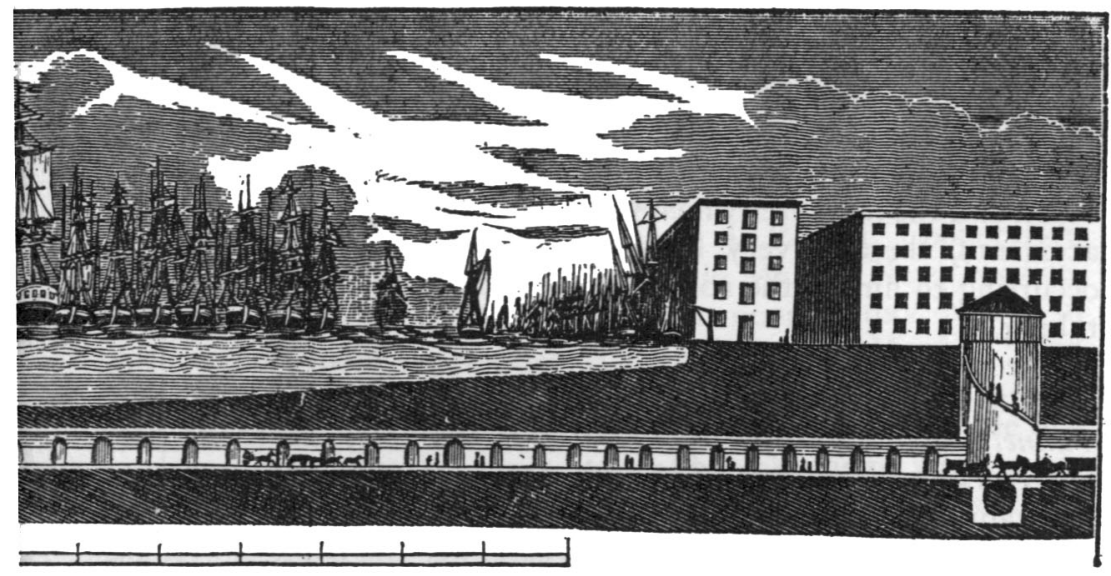

half completed

hundred feet under the river and the double archways in brickwork had been substantially completed.

In the following month the river broke in; and finally when in January, 1828 , the tunnel again filled with water, the project was temporarily abandoned. The engineer, not to be daunted, closed the chasms in the bed of the river where the irruptions had occurred, with strong bags of clay. When the tunnel was entered later, it was found to be quite satisfactory and perfectly sound, "thus affording the strongest proof of the efficiency of Mr. Brunel's system of constantly protecting as much as possible every part of the soil during the excavation, and finishing the structure in the most solid manner as the work proceeded; it being evident that the work already done must have been abandoned, if any part of it had been carried away by the irruption of the river." The finances of the company then being in such a precarious position that there was no surety of being able to complete the work, the tunnel was blocked in and work discontinued.

This unusual undertaking had caused considerable excitement not only in England but on the continent, and, after the aforementioned irruptions, several hundred plans for filling up the cavity and for preventing future accidents were submitted to the Board of Directors. None of them suggested any mode of proceeding, or any improvement over the "all-important shield." 
For seven years the work remained untouched, though the tunnel was nearly half completed and had cost with the shaft but $£$ I26,000 exclusive of machinery. As our little book went to press, the work had been recommenced. The editor of the volume prophesied that "from the experience gained during the progress of this unprecedented work, the difficulties which have been heretofore overcome, and the measures which will be adopted for preventing future accidents, there is very little probability of any circumstances occurring to hinder the complete success of this important undertaking."

The prediction proved to be correct, as we learn from another small volume entitled An Explanation of the Works of the Thames T'unnel now completed from Rotherhithe to Wapping, published for the Directors by Warring and Son in the Strand, London, I848. Among the staunchest supporters of this project through all its vicissitudes, which lasted for more than twenty years, was the Duke of Wellington. This edition tells us that "his Grace described it as 'a work important in a commercial as well as in a military and political point of view, and that there was no work upon which the public interest of foreign nations had been more excited than it had been upon this Tunnel!'” The work continued uninterruptedly after I 836 and the Thames Tunnel was opened to the public on March 24, I 843 . The shafts were equipped with circular staircases and were for the accommodation of foot passengers at a toll of one penny each. The Tunnel remained open day and night, being at all times illuminated with gas lamps. As though this "wonderful work of art" were not sufficient attraction to the public, in addition "a series of Fresco Paintings by I. B. Henkin, have been introduced in the Panels of the Shafts; no extra charge for admission beyond the Toll of One Penny." These frescoes consisted of thirty-two views of foreign and local spots of interest, to which were subjoined four allegorical paintings representing spring, summer, autumn and winter.

We learn from another source that though the tunnel had been constructed as a highway, the carriage entrances were never completed and, hence, it was never used for this purpose. The tunnel cost about $£_{433}$ per linear foot and is still one of the widest ever built under such conditions. In 1866 it was sold to the East London Railway which still operates its trains through it. Three years later Peter William Barlow employed an iron lining in connection with the shield he used for sinking the second tunnel under the Thames, and this method has since been extensively used in modern tunnel construction. 